\title{
Heterocyclic Compounds of some Natural Products as Anti-Covid-19: Iranian Plants and Natural Drugs of Ardabil Province
}

\author{
Nayer T. Mohammadian ${ }^{1}$, Majid Monajjemi ${ }^{2, *}$ (D) \\ 1 Department of Chemistry, Ardabil Branch, Islamic Azad University, Ardabil, Iran \\ 2 Department of Chemical engineering, central Tehran Branch, Islamic Azad University, Tehran, Iran \\ * Correspondence: maj.monajjemi@iauctb.ac.ir; m_monajjemi@yahoo.com;
}

Scopus Author ID 6701810683

Received: 8.10.2020; Revised: 10.11.2020; Accepted: 12.11.2020; Published: 15.11.2020

\begin{abstract}
Natural products make amazing opportunities for novel drugs via extracting of some heterocyclic compounds. These extracted molecules are used as anti-corona virus diseases. Herbal heterocyclic drugs are included in various forms, such as tablets, capsules, tinctures, and syrups. In Iran, with around 1.65 million $\mathrm{km}^{2}$ areas, the climate is diverse, ranging from arid and semi-arid to subtropical along the Caspian coast and the northern forests. The Moghan plain is located to the north of Ardabil province and west of the Caspian Sea. Due to its mild winters and humid summers, it is considered an important pole for Iran's agriculture and natural plant drugs. To date, scientists in Iran identified 10000 plant species; out of these, approximately 1000 are medicinal and aromatic plants, and around 100 species are in Ardabil province. Therefore, this province has rich medicinal plants and raw plant materials and processed herbal medicines to produce natural drug products as anti-COVID-19. This work simulated the heterocyclic molecules extracted from those plants for anti-COVID -19 drugs.
\end{abstract}

Keywords: natural product; COVID-19; Ardabil province; natural drugs; docking

(C) 2020 by the authors. This article is an open-access article distributed under the terms and conditions of the Creative Commons Attribution (CC BY) license (https://creativecommons.org/licenses/by/4.0/).

\section{Introduction}

\subsection{COVID-19 specification.}

COVID-19 is an enveloped, positive-sense messenger RNA virus that consists of the largest known RNA genomes (a length of up between 30-32 kb). This virus is a goal subject nowadays due to any investigation for helping humanity. Mainly virulent shapes have emerged from animal origins and pose a threat to human communities [1-5]. In 2003, the SARS appeared in China, moving from bat to humans, and 11 years after, the MERS emerged from bats again from bat to dromedary camels and eventually to humans. The genetic information of both SARS and MERS can help us with the details of COVID-19. Hopefully, we will develop new ways to fight them $[5,6]$. A few important types of these viruses, such as SARS-CoV-2 or COVID-19, can cause death in animals and humans. The proteins contain replication transcription complexes that make more RNA, various structural proteins, and two proteases. These proteases have important roles in cutting the poly-proteins insides all of the functional spaces. The protein folding of virus components is similar to serine proteases such as "Try" and also the cysteine amino acids that make the protein-cutting reaction close to "His" [7-9]. Those dimers exhibit peptides-like inhibitors active sites. The papain-like protease (Fig.1) has 
a unique subunit using Cys amino acid via the reaction, making three specific cuts in the SARS polyproteins[10,11].

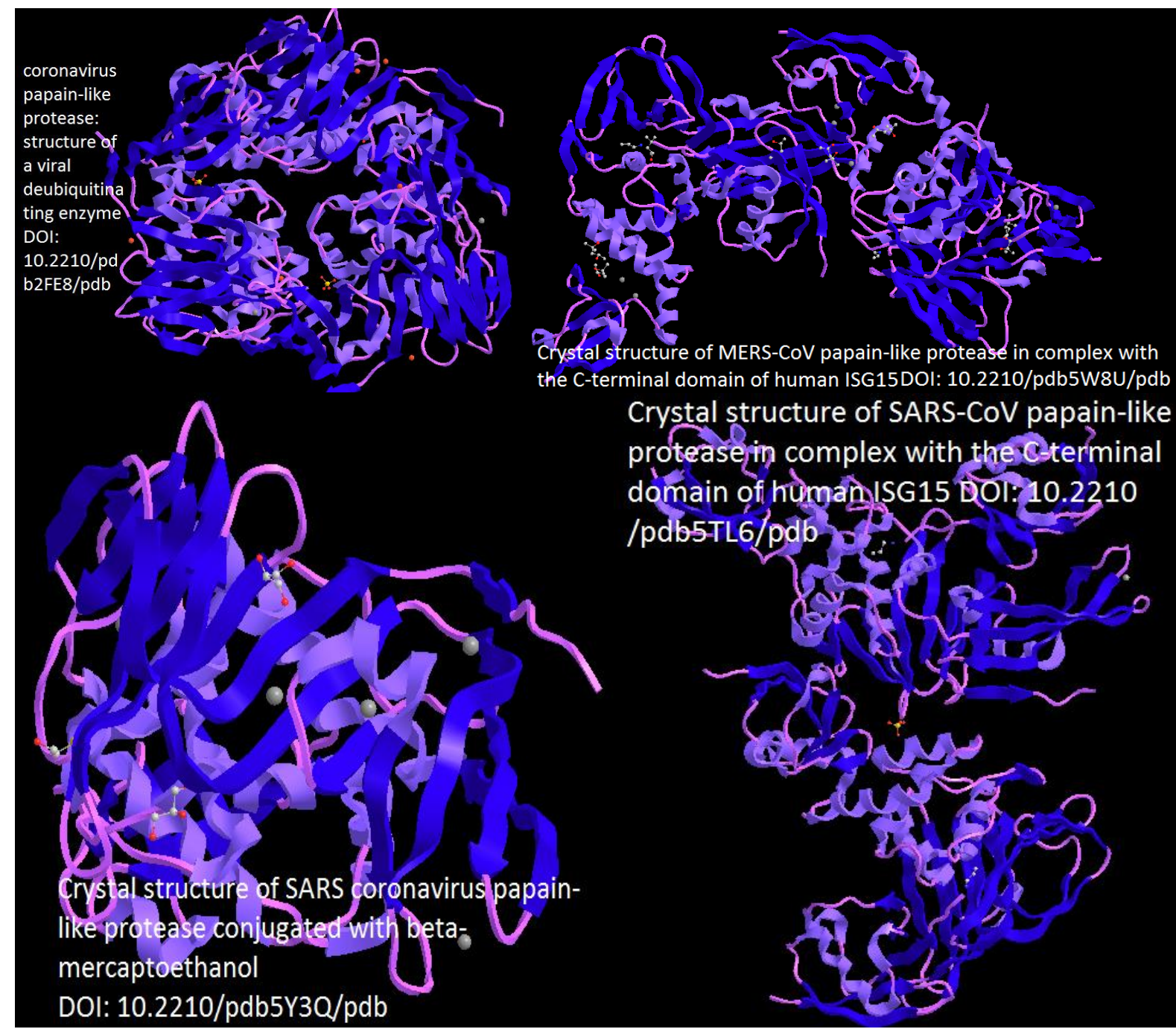

Figure 1. X-Ray Structural and Biological Evaluation of a Series of Potent and Highly Selective Inhibitors of Human Coronavirus Papain-Like Proteases.

Coronaviruses have been structured into 4 configurations that might be very different for any further drug simulation. The major way for modeling inhibitors against the progenitor bat coronavirus may be provided the keys to discover related inhibitors of those kinds of viruses. All components of COVID-19 synthesis, several non-structural proteins (NSP) where produced viral poly-proteins. Most varieties of CoV-NSPs possess enzyme activities that are related to RNA modification, and also the structures of this modification can be determined for many of the SARS-CoV-NSPs in isolation using X-ray crystallography and NMR. This study is accomplished due to the development of modern anti-covid-19 drugs. Several heterocyclic compounds are known as target drugs such as alkylating agents, which have targeted cell RNA, causing viruses' death. The Partition of COVID varieties and related structure of the single Nterminal for the virus polymerases have been introduced in (Scheme 1) [12-14]. Coronaviruses have been structured via unique-stranded RNA that is associated with a few natural hosts. COVID-19 is partitioned into alpha, beta, gamma, and delta categories. Among them, the beta group consists of A, B, C, and D subunits. All of the coronaviruses family are mentioned in the red rectangular frame, including 229E and NL63 in the $\alpha$ group, OC43, HKU1 in $\beta$ subgroup, and finally MERS-CoV (Middle East respiratory syndrome $\mathrm{CoV}$ ) in beta sub-group C [14-17]. 
Recently, SARS-CoV and MERS-CoV have been emerged in the human population and caused severe pulmonary disease with alarmingly high case-fatality rates. SARS-like-CoV and MERS-like-CoV also pose a great threat to public health in the world. Recent reviews and researches discovered a few types more of SL-CoV, such as SL-WIV1-CoV and SL-SHC014$\mathrm{CoV}$. Moreover, the ML-CoVs and bat CoV-HKU4 was shown to distinguish the MERS-CoVs receptors of the CD-26 and infect human cells after mutations of S746R with N762A) into its $S$ protein [18-21].

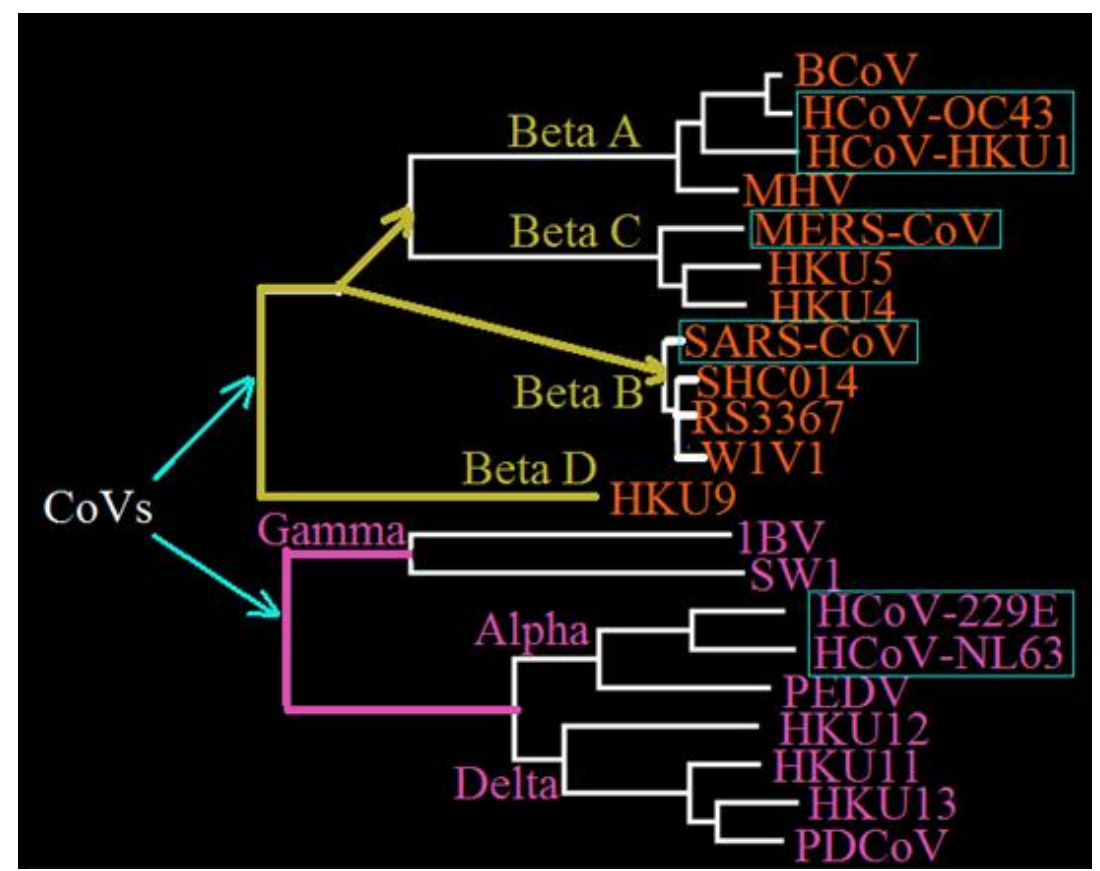

Scheme 1. Schematic trees created with coronaviruses family from the viewpoint of gen- groups.

As no anti-COVID drugs are currently available for any clinical usage, there are necessary for searching to keeping target based on properties of coronaviruses family, which via the $\mathrm{S}$ glycoprotein plays an important role in mediating viral infection. The $\mathrm{S}$-proteins consist of two subunits, S1 and S2 (Fig.2). Their subfamilies of Corona-virinae that include viruses of both medical and veterinary importance might be separated into the four genera alpha-, beta-, gamma- and delta-coronavirus $(\alpha-, \beta-, \gamma$ - and $\delta$-CoV). The coronavirus particle comprises at least the four canonical structural proteins $\mathrm{E}$ (envelope protein), $\mathrm{M}$ (membrane protein), $\mathrm{N}$ (nucleon-capsid protein), and $\mathrm{S}$ (spike protein).

\subsection{Heterocyclic compounds of natural products from Ardabil province.}

Heterocyclics are, in essence, composed of atoms other than carbon, where the most frequent substituents are $\mathrm{S}, \mathrm{O}$, and $\mathrm{N}$. The size of a heterocyclic ring with the substituent groups impacts tightly on the chemical and physical properties. In contrast, heterocyclic molecules have an active role as anti-bacterial, anti-viral, anti-fungal, anti-inflammatory, anti-tumor, and finally, among the clinical applications anti-COVID-19 agents. Several drugs are currently applied in the treatment of COVID-19, but most of them produced a controlled effect on the viral cells. These drugs are mostly belonging to a class of heterogeneous structures that play an important role in the metabolism of all COVID-19-cells complexes. Generally, biophysical $\&$ biochemical properties like donor-acceptor capability, hydrogen bond, $\pi-\pi$ stacking interactions, van der Waals, co-ordination bonds with metals, and in total hydrophobic forces have caused the increasing interest in anti-COVID-19 studies for such viruses. These properties 
are important for understanding how their reactivity enables derivatives to bind with various nucleic acids, enzymes, and biological structures [22, 27].

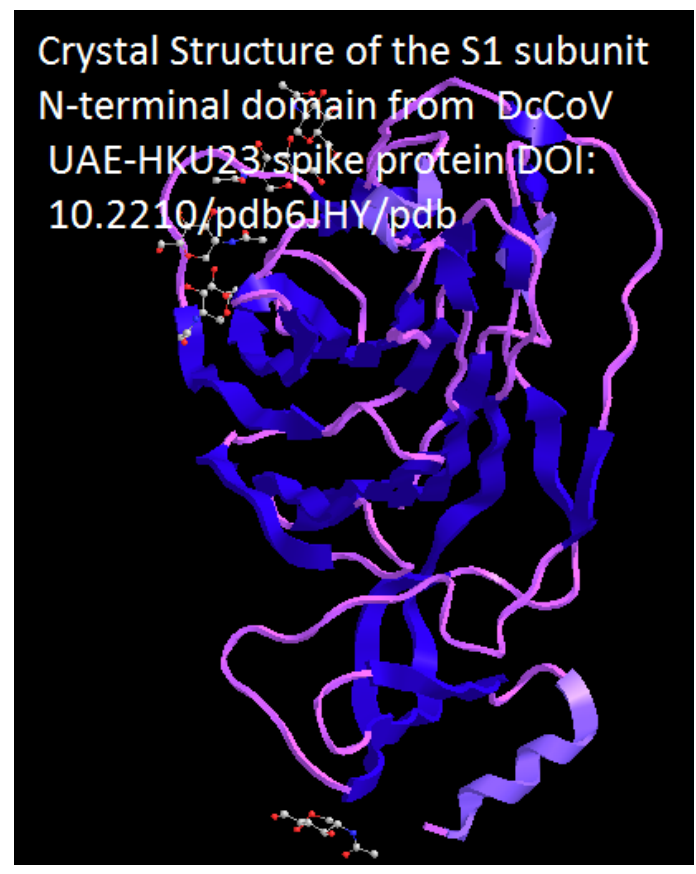

Figure 2. S1 subunit model of coronavirus.

Many of the heterocyclic molecules applied in medical drugs such as Proline, Histidine, Thiamine, riboflavin, pyridoxine, folic acid, biotin, $\mathrm{B}_{12}$, and $\mathrm{E}$ vitamins families. To investigate anti-fungal molecules, 1,3, 4oxadiazolo-(3,2a)-s-triazin-7-thione molecules and 1, 3, 4oxadiazole derivatives have been s synthesized. Fungi are hetero-tropic micro-organisms distinguished, including yeast that 1, 3, 4-oxa- Thiadiazolo (3-2a) pyrimidin-5-ones have been synthesized as anti-fungal drugs. The N-benzylidene-3, 4-dihydro-2, 2, 8-trimethyl- 2H-1benzopyran-7-yloxyacetie acid hydrazide, 1,3,4-oxadiazolo-[3,2-a]- 1,3,4-dithiazines have also been synthesized as anti-COVID-19 (Figure 3). By using a carcinogen inside a human body, the viral cell will not immediately act due to the latency effect. The initial step of a carcinogen will result in forming the irreversible initiated cells and then elapse before a second agent, known as the promoter, will act reversibly on the initiated cell giving a premalignant lesion. In all countries, COVID-19 disease is a major reason for human death due to unknown treatment and difficulty for curing. The main cause of this problem is that COVID-19 results from the uncontrolled and huge proliferation of normal cells. Vaccination is one of the important methods to intervene in somehow with the cell's RNA's operation. Anti-metabolites structures can be polymerized into RNA to destroy the functional agents in RNA, which attach to the RNA permanently and distorting its stability. Although these agents destroy many other molecules in host cells, RNA-binding agents bind to the RNA chain to break it and consequently attaching to another string, then repeat the process.

Sometimes cell's RNA makes a resistance for treatment due to cytotoxic drugs, which are given by a combination of drugs from several groups' side effects[28-31]. Applying a wide range of anti-COVID-19 drugs make them dangerous for short times. These side effects include losing hair, flaky skin, decreasing appetite, dry skin, change in taste, vomiting, fatigue, depression, decreasing the immune system, and blood clotting. Usually, although the advantages of using cytotoxic drugs in cell therapy are much more than the disadvantages, it is 
important to decrease the side effects of these kinds of drugs as possible, which are the subject of this work.
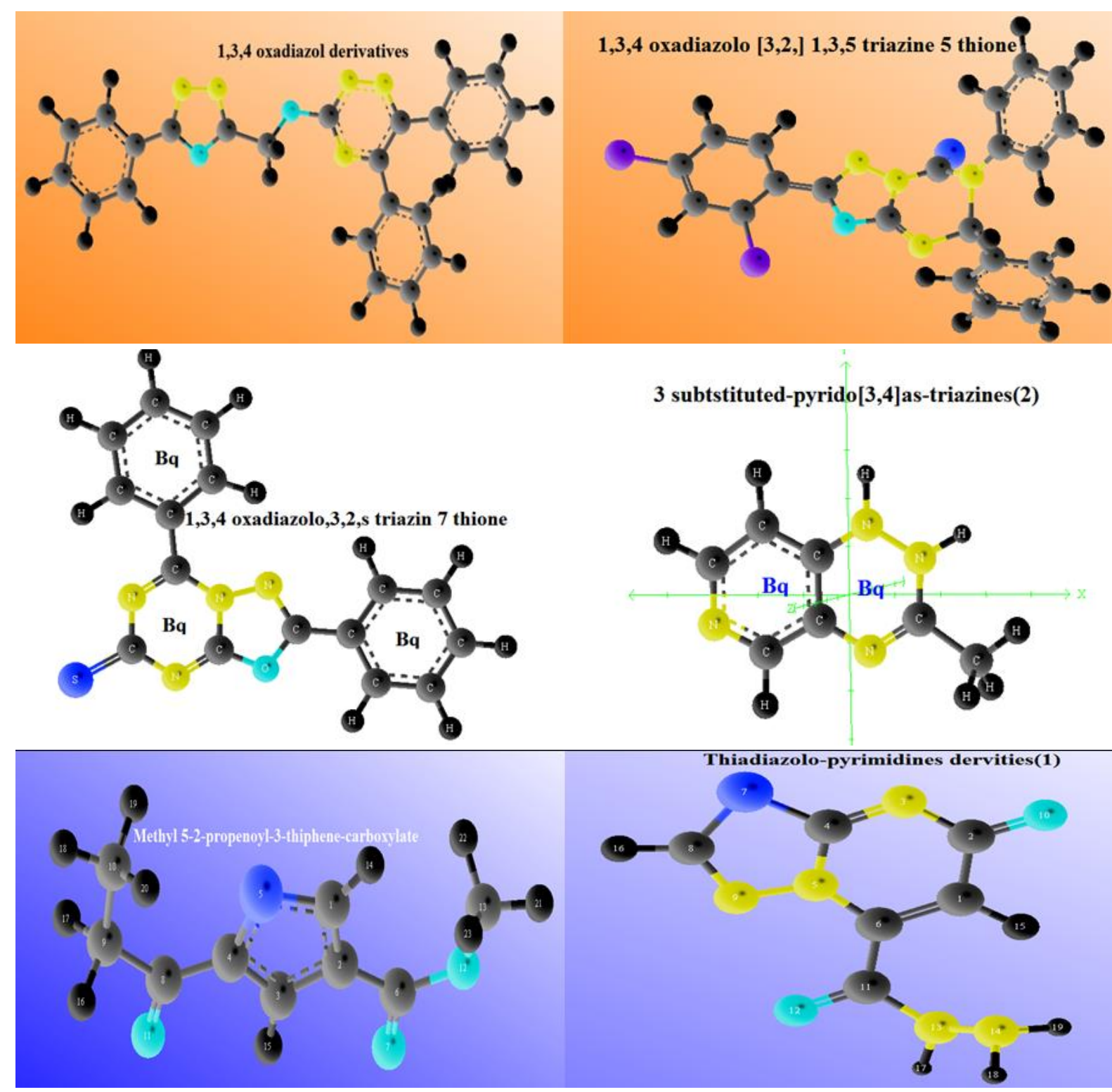

Figure 3. Optimization of 1, 3, 4 oxadiazol derivatives and 1, 3, 4 oxadiazolo $[3,2] 1,3,5$ triazine 5 thione , 1, 3, 4 oxadiazolo, 3, 2, s triazin 7 thione and 3 substituted-pyrido [3, 4] as-triazines and Methyl 5-2-propenoyl-3thiphene-carboxylate and Thiadiazolo-pyrimidines derivatives.

In this work, all anti-COVID-19 drugs are important natural products that are extracted from Ardabil's plants. This study is accomplished to develop a modern anti-corona-drugs. Many heterocyclic compounds are known as anti-COVID-19 drugs, such as alkylating agents, which have targeted cell DNA, causing cell death. This work is done via efficient natural products by focusing on the development of anti-COVID- drugs through the aromaticity function[32-37].

\section{Materials and Methods}

\subsection{Proteins/macromolecules.}

COVID-19 PDB IDs: 5Y3Q, 5W8U, 6BI8, 6JHY, 5TL6 and 2FE8 files in .pdb format have been selected. PDB is an archive for the crystal structures of biological macromolecules 
worldwide [14]. Soe of them protein contains two chains, A and B, which form a homodyne. Chain A was used for macromolecule preparation. The 3-dimensional (3D) structures were extracted from PubChem (https://pubchem.ncbi.nlm.nih.gov/)[38], in .sdf format. Pub-Chem is a chemical substance and biological activities repository consisting of three databases, including substance, compound, and bioassay databases. Several ligands for which the active compound can be extracted from herbal medicine office located in Ardabil Province. The amino acids in the active site of a protein were determined using the Computed Atlas for Surface Topography of Proteins (CASTp) (http://sts.bioe.uic.edu/castp/index.) and Biovia. Discovery Studio 4.5. The distinguished amino acids in the active sites were used to analyze the Grid box and docking evaluation results.

\subsection{Molecular docking.}

Based on our previous works[39-93], Molecular Optimizations were accomplished via Gaussian, Charmm amber, and Avogadro version 1.2, with Force Fields type MM and MMFF94. In this work Auto-dock version 4.2, this supported by Auto dock Tools, MGL tools, and Rasmol. In addition, iGEMDOCK software has been applied for protein optimizations. Through this software, the suitable receptor was selected for the binding site in whole COVID19 protein structures by removing water and other atoms and then adding a polar hydrogen group. The protein composition is worked with a ligand, and iGEMDOCK can help define the suitable binding site. Auto-grid then determined the native ligand position on the binding site by arranging the grid coordinates (X, Y, and Z). The following steps have been done in docking simulation :( a), Prepare Binding Site on the Protein-Ligand. (b) Browsing and selecting the protein file. (c) Defining the binding site type as a bounded ligand. (d) Defining the center of the binding site by selected ligand. (e) Setting the size of the binding site through the extended radius from the selected ligand. IGEMDOCK yields an analysis surrounding visualized tools and post-analysis tools for users, which can visualize the docked states, and categories through the protein-ligand interactions. Consequently, the prediction and scores of ligands can be saved in the output path. The minimum energies pose of each ligand will be outputted into the location of "best: Pose". These analysis tools are premeditated based on the analysis of those poses. Via looking for some ligands' bounded structures, they can be select via the check box of the ligand. If the co-crystallized ligands are retained on the binding site structures, it will be predicted poses. Cluster analysis is the partitioning of a data set into subsets. The data in each ideal subset will share some common traits. Ligand tethering of the protein was performed by regulating the genetic algorithm (GA) parameters, using 10 runs of the GA criteria.

\section{Results and Discussion}

\subsection{Results.}

Several natural products from Ardabil providence, such as molecules that are listed in table 1, from medicinal plants, have been reported to show anti-viral bioactivities. An analysis study exhibited that those compounds have strong bonding in active sites of proteins component in COVID-19. The binding energies obtained from the docking of those molecules in table 1 are listed in table 2. Table 1 exhibits the structures and amino acids found in the active site pockets of proteins that are found in COVID-19, which are also the main protease found in the $\mathrm{CoV}$ associated with the severe acute respiratory syndrome (SARS). The amino acids abbreviation are listed in table 1 as follows: Alanine(Ala, A), Arginine (Arg, R), 
Asparagine (Asn, N), Aspartic acid (Asp, D), Cysteine (Cys, C), Glutamic acid (Glu, E), Glutamine (Gln, Q), Glycine (Gly, G), Histidine (His, H), Isoleucine (Ile, I), Leucine (Leu, L), Lysine (Lys, K), Methionine (Met, M), Phenylalanine (Phe, F), Proline (Pro, P), Serine (Ser, S), Threonine (Thr, T), Tryptophan (Trp, W), Tyrosine (Tyr, Y) and Valine (Val, V).

Table 1. Protein target structures and active site amino acids (Biovia Discovery Studio 4.5, 2019) and the native

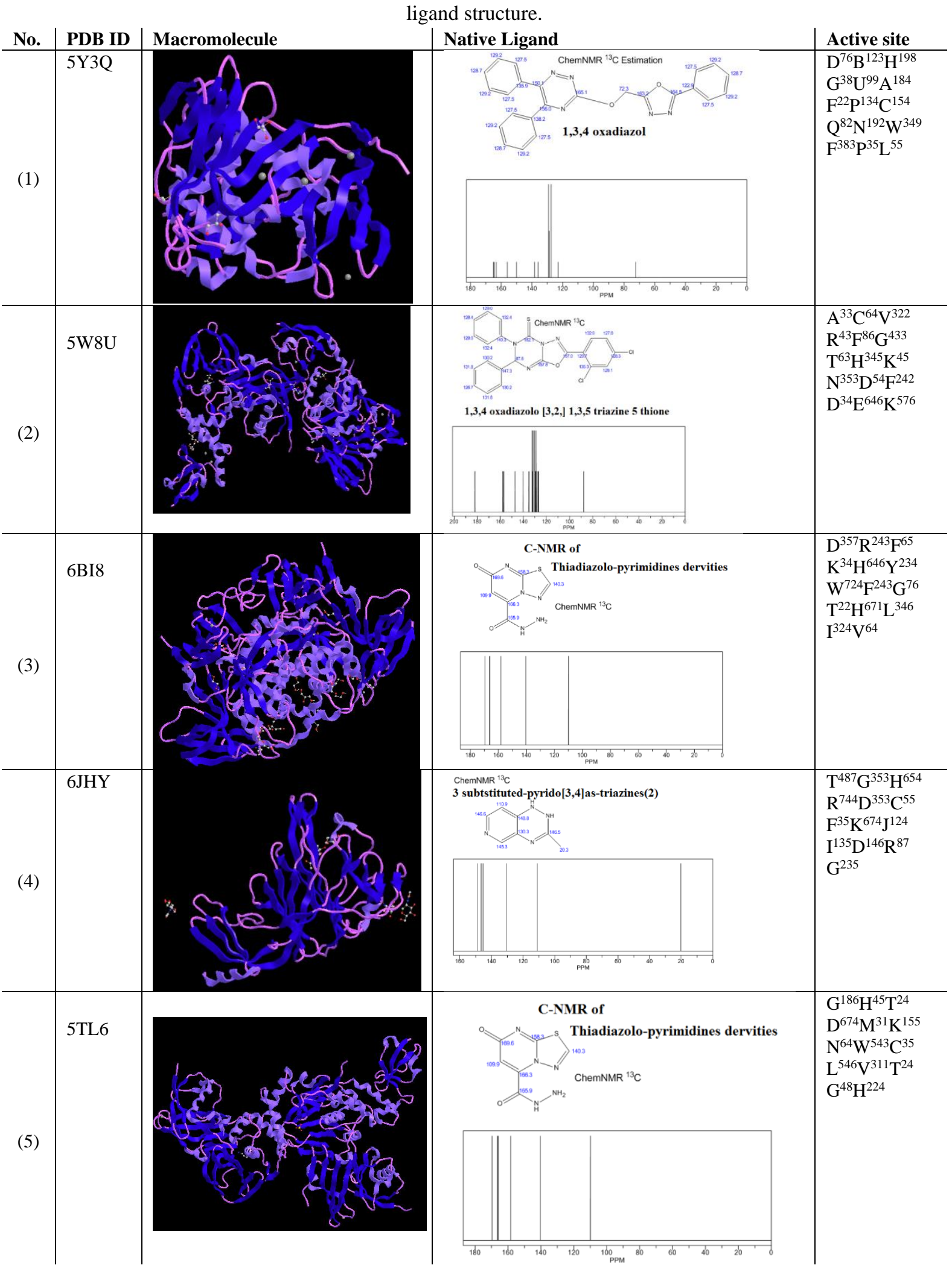




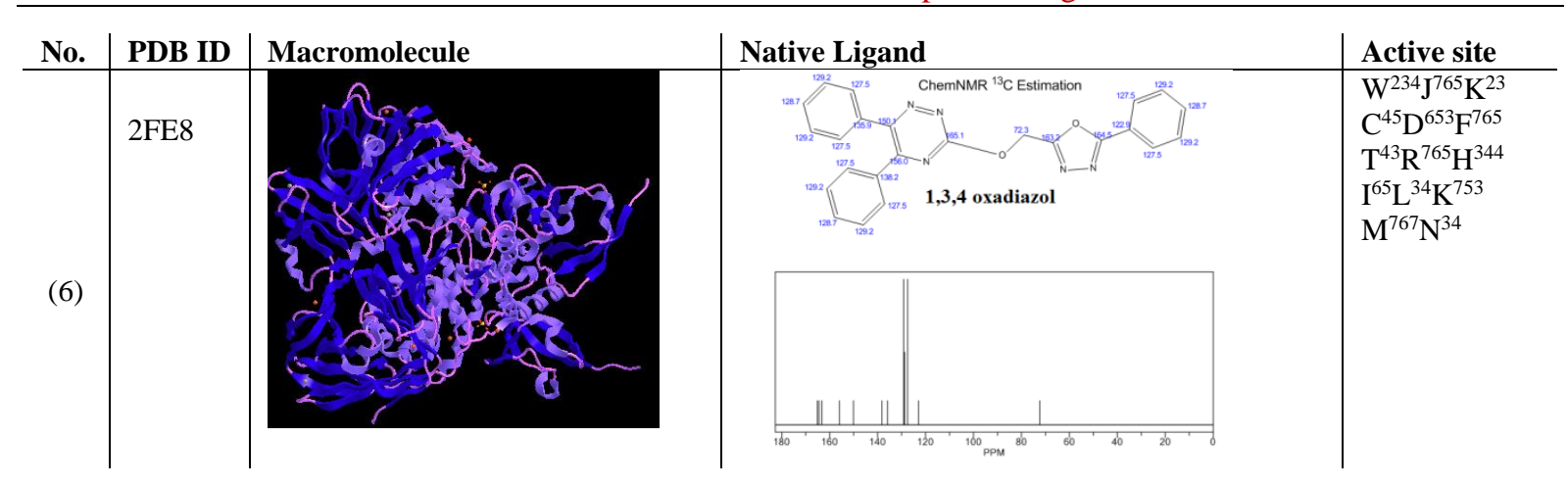

\subsection{Discussion.}

Among the herbal medicine, six Native Ligand as the source for active constituents to be examined as to its potential as anti-SARS-CoV-2, extracted from Moghan plants in Ardabil province in Iran. We used several representative compounds of each plant, which are known to have pharmacological benefits. These plants are also important for the health and human immune system among the Iran population in relation to those of the active constituents. We used molecular docking with several receptors; receptor human ACE2 of six PDB IDs in table 1. The result showed that several compounds could bind finely to the target receptors at the expected sides'. Several Gibbs energy of binding energies were calculated through docking calculations (Table 2).

Interestingly, we exhibited that these compounds accomplish superior binding affinities to each receptor. These higher binding affinities of those compounds could significantly represent their stronger inhibitory activities to the viral infection. These findings indicated that all compounds possess better binding interaction and may inhibit the host cell's initial virus infection [94-106].

Although the bio drug delivery research and works' growths have a prevalent area over the past couple of decades, the monthly number of new treatments agreed with the drug organization. Compared to the clinical activities, drug reusing for viruses, including the novel coronavirus, is demonstrated as major impacted drug discovery strategies from existing drugs and could essentially shorten the time and reduce the cost [107-119]. Recently, Iranian medicinal plants were classified as anti-viral inhibitors of the novel COVID 19. The anticoronavirus effects of these natural derivatives have been confirmed in vitro via direct loading onto cultured cells; however, it does not guarantee their effectiveness in vivo.

Table 2. Docking score of natural compounds towards several potential binding domains of SARS-CoV-2,

\begin{tabular}{|c|c|c|c|c|c|c|}
\hline \multicolumn{7}{|c|}{ Energy Gibbs (kcal/mol). } \\
\hline Ligand & (1) & (2) & (3) & (4) & (5) & (6) \\
\hline 1, 3, 4-oxadiazole & -7.23 & -9.33 & -8.35 & -7.33 & -8.14 & -7.44 \\
\hline $\begin{array}{l}\text { 1,3, 4oxadiazolo-(3,2a)-s- } \\
\text { triazin-7-thione }\end{array}$ & -6.85 & -8.88 & -9.33 & -7.63 & -8.12 & -7.55 \\
\hline $\begin{array}{l}\text { 1,3,4-oxa- Thiadiazolo } \\
\text { (3- 2a) pyrimidin-5 }\end{array}$ & -8.43 & -7.43 & -8.35 & -8.33 & -7.88 & -6.99 \\
\hline $\begin{array}{l}\text { N-benzylidene-3, 4- } \\
\text { dihydro-2, 2, 8-trimethyl- } \\
\text { 2H-1-benzopyran-7- } \\
\text { yloxyacetie acid hydrazide }\end{array}$ & -7.28 & -9.33 & -6.99 & -8.56 & -8.01 & -8.05 \\
\hline $\begin{array}{l}\text { 1,3,4-oxadiazolo-[3,2-a]- } \\
\text { 1,3,4-dithiazines }\end{array}$ & -7.33 & -7.54 & -8.44 & -9.54 & -9.12 & -8.19 \\
\hline $\begin{array}{l}\text { 1, 3, 4-oxadiazole } \\
\text { derivatives }\end{array}$ & -8.34 & -8.12 & -8.21 & -7.44 & -8.11 & -7.29 \\
\hline
\end{tabular}




\section{Conclusions}

We exhibited that these natural products have suitable binding affinities to each ligand. These higher binding affinities of those molecules could represent significantly of their stronger inhibitory activities to the viral infection. Our molecular modeling also exhibited that heterocyclic compounds bind to those receptors with lower energies than the respected reference systems. These findings indicate that all compounds possess better binding interaction and may inhibit the host cell's initial virus infection.

\section{Funding}

This research was funded (1000\$) by ourselves.

\section{Acknowledgments}

Thanks to the Central Tehran Branch, Islamic Azad University for supporting computational software and all necessary equipment.

\section{Conflicts of Interest}

The authors declare no conflict of interest.

\section{References}

1. Cui, J.; Li, F.; Shi, Z.-L. Origin and evolution of pathogenic coronaviruses. Nature Reviews Microbiology 2019, 17, 181-192, https://doi.org/10.1038/s41579-018-0118-9.

2. St. John, S.E.; Tomar, S.; Stauffer, S.R.; Mesecar, A.D. Targeting zoonotic viruses: Structure-based inhibition of the 3C-like protease from bat coronavirus HKU4-The likely reservoir host to the human coronavirus that causes Middle East Respiratory Syndrome (MERS). Biorg. Med. Chem. 2015, 23, 60366048, https://doi.org/10.1016/j.bmc.2015.06.039.

3. Báez-Santos, Y.M.; Barraza, S.J.; Wilson, M.W.; Agius, M.P.; Mielech, A.M.; Davis, N.M.; Baker, S.C.; Larsen, S.D.; Mesecar, A.D. X-ray Structural and Biological Evaluation of a Series of Potent and Highly Selective Inhibitors of Human Coronavirus Papain-like Proteases. J. Med. Chem. 2014, 57, 2393-2412, https://doi.org/10.1021/jm401712t.

4. Hilgenfeld, R. From SARS to MERS: crystallographic studies on coronaviral proteases enable anti-viral drug design. The FEBS Journal 2014, 281, 4085-4096, https://doi.org/10.1111/febs.12936.

5. Sevajol, M.; Subissi, L.; Decroly, E.; Canard, B.; Imbert, I. Insights into RNA synthesis, capping, and proofreading mechanisms of SARS-coronavirus. Virus Res. 2014, 194, 90-99, https://doi.org/10.1016/j.virusres.2014.10.008.

6. Lehmann, K.C.; Gulyaeva, A.; Zevenhoven-Dobbe, J.C.; Janssen, George M.C.; Ruben, M.; Overkleeft, H.S.; van Veelen, P.A.; Samborskiy, Dmitry V.; Kravchenko, A.A.; Leontovich, A.M.; Sidorov, I.A.; Snijder, E.J.; Posthuma, C.C.; Gorbalenya, A.E. Discovery of an essential nucleotidylating activity associated with a newly delineated conserved domain in the RNA polymerase-containing protein of all nidoviruses. Nucleic Acids Res. 2015, 43, 8416-8434, https://doi.org/10.1093/nar/gkv838.

7. Peersen, O.B. Picornaviral polymerase structure, function, and fidelity modulation. Virus Res. 2017, 234, 420, https://dx.doi.org/10.1016\%2Fj.virusres.2017.01.026.

8. Baez-Santos, Y.M.;Mielech,A.M.; Deng, X.; Baker, S.; Mesecar, A.D.; Catalytic Function and Substrate Specificity of the Papain-Like Protease Domain of nsp3 from the Middle East Respiratory Syndrome Coronavirus, Journal of virology, 2014, 88, 12511-12527 21, 10.1128/JVI.01294-14

9. Woo, P.C.Y.; Lau, S.K.P.; Lam, C.S.F.; Lau, C.C.Y.; Tsang, A.K.L.; Lau, J.H.N.; Bai, R.; Teng, J.L.L.; Tsang, C.C.C.; Wang, M.; Zheng, B.-J.; Chan, K.-H.; Yuen, K.-Y. Discovery of Seven Novel Mammalian And Avian Coronaviruses In The Genus Deltacoronavirus Supports Bat Coronaviruses As The Gene Source Of Alphacoronavirus And Betacoronavirus And Avian Coronaviruses As The Gene Source Of Gammacoronavirus And Deltacoronavirus. J. Virol. 2012, 86, 3995, https://doi.org/10.1128/JVI.06540-11.

10. Su, S.S.; Wong, G.; Shi, W.; Liu, J.; Lai, A.C.K.; Zhou, J.; Liu, W.; Bi, Y.H.; Gao, G.F. Epidemiology, genetic recombination, and pathogenesis of coronaviruses. Trends Microbiol. 2016, 24, 490-502, https://doi.org/10.1016/j.tim.2016.03.003. 
11. Simon, A.; Völz, S.; Höfling, K.; Kehl, A.; Tillman, R.; Müller, A.; Kupfer, B.; Eis-Hübinger, A.-M.; Lentze, M.J.; Bode, U.; Schildgen, O. Acute life threatening event (ALTE) in an infant with human coronavirus HCoV-229E infection. Pediatr. Pulmonol. 2007, 42, 393-396, https://doi.org/10.1002/ppul.20595.

12. Morfopoulou, S.; Brown, J.R.; Davies, E.G.; Anderson, G.; Virasami, A.; Qasim, W.; Chong, W.K.; Hubank, M.; Plagnol, V.; Desforges, M.; Jacques, T.S.; Talbot, P.J.; Breuer, J. Human Coronavirus OC43 Associated with Fatal Encephalitis. New Engl. J. Med. 2016, 375, 497-498, https://doi.org/10.1056/NEJMc1509458.

13. Mayer, K.; Nellessen, C.; Hahn-Ast, C.; Schumacher, M.; Pietzonka, S.; Eis-Hübinger, A.M.; Drosten, C.; Brossart, P.; Wolf, D. Fatal outcome of human coronavirus NL63 infection despite successful viral elimination by IFN-alpha in a patient with newly diagnosed ALL. Eur. J. Haematol. 2016, 97, 208-210, https://doi.org/10.1111/ejh.12744.

14. Al-Khannaq, M.N.; Ng, K.T.; Oong, X.Y.; Pang, Y.K.; Takebe, Y.; Chook, J.B.; Hanafi, N.S.; Kamarulzaman, A.; Tee, K.K. Molecular epidemiology and evolutionary histories of human coronavirus OC43 and HKU1 among patients with upper respiratory tract infections in Kuala Lumpur, Malaysia. Virol J. 2016, 13, 33, https://doi.org/10.1186/s12985-016-0488-4.

15. Oong, X.Y.; Ng, K.T.; Takebe, Y.; Ng, L.J.; Chan, K.G.; Chook, J.B.; Kamarulzaman, A.; Tee, K.K. Identification and evolutionary dynamics of two novel human coronavirus OC43 genotypes associated with acute respiratory infections: phylogenetic, spatiotemporal and transmission network analyses. Emerging Microbes \& Infections 2017, 6, 1-13, https://dx.doi.org/10.1038\%2Femi.2016.132.

16. Lau, S.K.P.; Lee, P.; Tsang, A.K.L.; Yip, C.C.Y.; Tse, H.; Lee, R.A.; So, L.-Y.; Lau, Y.-L.; Chan, K.-H.; Woo, P.C.Y.; Yuen, K.-Y. Molecular Epidemiology of Human Coronavirus OC43 Reveals Evolution of Different Genotypes over Time and Recent Emergence of a Novel Genotype due to Natural Recombination. J. Virol. 2011, 85, 11325, https://doi.org/10.1128/JVI.05512-11.

17. Menachery, V.D.; Yount, B.L.; Sims, A.C.; Debbink, K.; Agnihothram, S.S.; Gralinski, L.E.; Graham, R.L.; Scobey, T.; Plante, J.A.; Royal, S.R.; Swanstrom, J.; Sheahan, T.P.; Pickles, R.J.; Corti, D.; Randell, S.H.; Lanzavecchia, A.; Marasco, W.A.; Baric, R.S. SARS-like WIV1-CoV poised for human emergence. Proceedings of the National Academy of Sciences 2016, 113, 3048, https://doi.org/10.1073/pnas.1517719113.

18. Yang, Y.; Liu, C.; Du, L.; Jiang, S.; Shi, Z.; Baric, R.S.; Li, F. Two Mutations Were Critical for Bat-toHuman Transmission of Middle East Respiratory Syndrome Coronavirus. J. Virol. 2015, 89, 9119, https://doi.org/10.1128/JVI.01279-15.

19. Park, Y.-J.; Walls, A.C.; Wang, Z.; Sauer, M.M.; Li, W.; Tortorici, M.A.; Bosch, B.-J.; DiMaio, F.; Veesler, D. Structures of MERS-CoV spike glycoprotein in complex with sialoside attachment receptors. Nat. Struct. Mol. Biol. 2019, 26, 1151-1157, https://doi.org/10.1038/s41594-019-0334-7.

20. Chan, J.F.-W.; To, K.K.-W.; Tse, H.; Jin, D.-Y.; Yuen, K.-Y. Interspecies transmission and emergence of novel viruses: lessons from bats and birds. Trends Microbiol. 2013, 21, 544-555, http://dx.doi.org/10.1016/j.tim.2013.05.005.

21. Racaniello, V.R.; Skalka, A.M.; Flint, J.; Rall, G.F. Principles of Virology, Bundle. $4^{\text {th }}$ Edition. American Society of Microbiology, Washington, DC, 2015.

22. Bosch, B.J.; van der Zee, R.; de Haan, C.A.M.; Rottier, P.J.M. The Coronavirus Spike Protein Is a Class I Virus Fusion Protein: Structural and Functional Characterization of the Fusion Core Complex. J. Virol. 2003, 77, 8801https://doi.org/10.1128/jvi.77.16.8801-8811.2003.

23. Baker, K.A.; Dutch, R.E.; Lamb, R.A.; Jardetzky, T.S. Structural Basis for Paramyxovirus-Mediated Membrane Fusion. Mol. Cell 1999, 3, 309-319, http://dx.doi.org/10.1016/S1097-2765(00)80458-X.

24. Bartesaghi, A.; Merk, A.; Borgnia, M.J.; Milne, J.L.S.; Subramaniam, S. Prefusion structure of trimeric HIV-1 envelope glycoprotein determined by cryo-electron microscopy. Nat. Struct. Mol. Biol. 2013, 20, 1352-1357, http://dx.doi.org/10.1038/nsmb.2711.

25. Lin, X.; Eddy, N.R.; Noel, J.K.; Whitford, P.C.; Wang, Q.; Ma, J.; Onuchic, J.N. Order and disorder control the functional rearrangement of influenza hemagglutinin. Proceedings of the National Academy of Sciences 2014, 111, 12049, http://dx.doi.org/10.1073/pnas.1412849111.

26. Hofmann, H.; Hattermann, K.; Marzi, A.; Gramberg, T.; Geier, M.; Krumbiegel, M.; Kuate, S.; Überla, K.; Niedrig, M.; Pöhlmann, S. S Protein of Severe Acute Respiratory Syndrome-Associated Coronavirus Mediates Entry into Hepatoma Cell Lines and Is Targeted by Neutralizing Antibodies in Infected Patients. J. Virol. 2004, 78, 6134, http://dx.doi.org/10.1128/JVI.78.12.6134-6142.2004.

27. Walls, A.C.; Tortorici, M.A.; Bosch, B.-J.; Frenz, B.; Rottier, P.J.M.; DiMaio, F.; Rey, F.A.; Veesler, D. Cryo-electron microscopy structure of a coronavirus spike glycoprotein trimer. Nature 2016, 531, 114-117, http://dx.doi.org/10.1038/nature16988.

28. Kirchdoerfer, R.N.; Cottrell, C.A.; Wang, N.; Pallesen, J.; Yassine, H.M.; Turner, H.L.; Corbett, K.S.; Graham, B.S.; McLellan, J.S.; Ward, A.B. Pre-fusion structure of a human coronavirus spike protein. Nature 2016, 531, 118-121, http://dx.doi.org/10.1038/nature17200.

29. Reguera, J.; Santiago, C.; Mudgal, G.; Ordoño, D.; Enjuanes, L.; Casasnovas, J.M. Structural Bases of Coronavirus Attachment to Host Aminopeptidase $\mathrm{N}$ and Its Inhibition by Neutralizing Antibodies. PLoS Path. 2012, 8, e1002859, https://dx.doi.org/10.1371\%2Fjournal.ppat.1002859. 
30. Akimkin, V.; Beer, M.; Blome, S.; Hanke, D.; Höper, D.; Jenckel, M.; Pohlmann, A. New Chimeric Porcine Coronavirus in Swine Feces, Germany, 2012. Emerging Infectious Disease journal 2016, 22, 1314, https://dx.doi.org/10.3201/eid2207.160179.

31. Wu, K.; Li, W.; Peng, G.; Li, F. Crystal structure of NL63 respiratory coronavirus receptor-binding domain complexed with its human receptor. Proceedings of the National Academy of Sciences 2009, 106, 19970, http://dx.doi.org/10.1073/pnas.0908837106.

32. Duquerroy, S.; Vigouroux, A.; Rottier, P.J.M.; Rey, F.A.; Jan Bosch, B. Central ions and lateral asparagine/glutamine zippers stabilize the post-fusion hairpin conformation of the SARS coronavirus spike glycoprotein. Virology 2005, 335, 276-285, http://dx.doi.org/10.1016/j.virol.2005.02.022.

33. Gao, J.; Lu, G.; Qi, J.; Li, Y.; Wu, Y.; Deng, Y.; Geng, H.; Li, H.; Wang, Q.; Xiao, H.; Tan, W.; Yan, J.; Gao, G.F. Structure of the Fusion Core and Inhibition of Fusion by a Heptad Repeat Peptide Derived from the S Protein of Middle East Respiratory Syndrome Coronavirus. J. Virol. 2013, 87, 13134, http://dx.doi.org/10.1128/JVI.02433-13.

34. Xu, Y.; Lou, Z.; Liu, Y.; Pang, H.; Tien, P.; Gao, G.F.; Rao, Z. Crystal structure of severe acute respiratory syndrome coronavirus spike protein fusion core. J. Biol. Chem. 2004, 279, 49414-49419, http://dx.doi.org/10.1074/jbc.M408782200.

35. Ou, X.; Zheng, W.; Shan, Y.; Mu, Z.; Dominguez, S.R.; Holmes, K.V.; Qian, Z. Identification of the Fusion Peptide-Containing Region in Betacoronavirus Spike Glycoproteins. J. Virol. 2016, 90, 5586, https://doi.org/10.1128/JVI.00015-16.

36. Lu, G.; Hu, Y.; Wang, Q.; Qi, J.; Gao, F.; Li, Y.; Zhang, Y.; Zhang, W.; Yuan, Y.; Bao, J.; Zhang, B.; Shi, Y.; Yan, J.; Gao, G.F. Molecular basis of binding between novel human coronavirus MERS-CoV and its receptor CD26. Nature 2013, 500, 227-231, http://dx.doi.org/10.1038/nature12328.

37. Lu, L.; Liu, Q.; Zhu, Y.; Chan, K.-H.; Qin, L.; Li, Y.; Wang, Q.; Chan, J.F.-W.; Du, L.; Yu, F.; Ma, C.; Ye, S.; Yuen, K.-Y.; Zhang, R.; Jiang, S. Structure-based discovery of Middle East respiratory syndrome coronavirus fusion inhibitor. Nature Communications $2014, \quad 5, \quad 3067$, http://dx.doi.org/10.1038/ncomms4067.

38. Kim, S.; Chen, J.; Cheng, T.; et al. PubChem 2019 update: improved access to chemical data. Nucleic Acids Res. 2019;47(D1):D1102-D1109. doi:10.1093/nar/gky1033

39. Mollaamin, F.; Monajjemi, M. DFT outlook of solvent effect on function of nano bioorganic drugs. Phys. Chem. Liq. 2012, 50, 596-604, https://doi.org/10.1080/00319104.2011.646444.

40. Mollaamin, F.; Gharibe, S.; Monajjemi, M. Synthesis of various nano and micro ZnSe morphologies by using hydrothermal method. International Journal of the Physical Sciences 2011, 6, 1496-1500.

41. Monajjemi M. Graphene/(h-BN)n/X-doped raphene as anode material in lithium ion batteries $(\mathrm{X}=\mathrm{Li}, \mathrm{Be}$, B AND N). Macedonian Journal of Chemistry and Chemical Engineering 2017, 36, 101-118, http://dx.doi.org/10.20450/mjcce.2017.1134.

42. Monajjemi, M. Cell membrane causes the lipid bilayers to behave as variable capacitors: A resonance with self-induction of helical proteins. Biophys. Chem. 2015, 207, 114-127, https://doi.org/10.1016/j.bpc.2015.10.003.

43. Monajjemi, M. Study of CD5+ Ions and Deuterated Variants $(\mathrm{CHxD}(5-\mathrm{x})+)$ : An Artefactual Rotation. Russian Journal of Physical Chemistry A 2018, 92, 2215-2226.

44. Monajjemi, M. Liquid-phase exfoliation (LPE) of graphite towards graphene: An ab initio study. J. Mol. Liq. 2017, 230, 461-472, https://doi.org/10.1016/j.molliq.2017.01.044.

45. Jalilian, H.; Monajjemi, M. Capacitor simulation including of $\mathrm{X}$-doped graphene $(\mathrm{X}=\mathrm{Li}, \mathrm{Be}, \mathrm{B})$ as two electrodes and $(\mathrm{h}-\mathrm{BN}) \mathrm{m}(\mathrm{m}=1-4)$ as the insulator. Jpn. J. Appl. Phys. 2015, 54, 085101.

46. Ardalan, T.; Ardalan, P.; Monajjemi, M. Nano Theoretical Study of a C16 Cluster as a Novel Material for Vitamin C Carrier. Fullerenes, Nanotubes and Carbon Nanostructures 2014, 22, 687-708, https://doi.org/10.1080/1536383X.2012.717561.

47. Mahdavian, L.; Monajjemi, M.; Mangkorntong, N. Sensor Response to Alcohol and Chemical Mechanism of Carbon Nanotube Gas Sensors. Fullerenes, Nanotubes and Carbon Nanostructures 2009, 17, 484-495, https://doi.org/10.1080/15363830903130044.

48. Monajjemi, M.; Najafpour, J. Charge Density Discrepancy Between NBO and QTAIM in Single-wall Armchair Carbon Nanotubes. Fullerenes, Nanotubes and Carbon Nanostructures 2014, 22, 575-594, https://doi.org/10.1080/1536383X.2012.702161.

49. Monajjemi, M.; Seyed Hosseini, M. Non Bonded Interaction of B16N16 Nano Ring with Copper Cations in Point of Crystal Fields. Journal of Computational and Theoretical Nanoscience 2013, 10, 2473-2477, https://doi.org/10.1166/jctn.2013.3233.

50. Monajjemi, M.; Mahdavian, L.; Mollaamin, F. Characterization of nanocrystalline silicon germanium film and nanotube in adsorption gas by Monte Carlo and Langevin dynamic simulation. Bull. Chem. Soc. Ethiop. 2008, 22, 277-286, https://doi.org/10.4314/bcse.v22i2.61299.

51. Lee, V.S.; Nimmanpipug, P.; Mollaamin, F.; Kungwan, N.; Thanasanvorakun, S.; Monajjemi, M. Investigation of single wall carbon nanotubes electrical properties and normal mode analysis: Dielectric effects. Russian Journal of Physical Chemistry A 2009, 83, 2288-2296, https://doi.org/10.1134/S0036024409130184. 
52. Mollaamin, F.; Najafpour, J.; Ghadami, S.; Ilkhani, A.R.; Akrami, M.S.; Monajjemi, M. The Electromagnetic Feature of B15N15H x ( $\mathrm{x}=0,4,8,12,16$, and 20) Nano Rings: Quantum Theory of Atoms in Molecules/NMR Approach. Journal of computational and theoretical nanoscience 2014, 11, 1290-1298.

53. Monajjemi, M.; Mahdavian, L.; Mollaamin, F.; Honarparvar, B. Thermodynamic Investigation of Enol $\leftrightarrow$ Keto Tautomerism for Alcohol Sensors Based on Carbon Nanotubes as Chemical Sensors. Fullerenes, Nanotubes and Carbon Nanostructures 2010, 18, 45-55, https://doi.org/10.1080/15363830903291564.

54. Monajjemi, M.; Ghiasi, R.; Sadjadi, M.A.S. Metal-stabilized rare tautomers: N4 metalated cytosine $(\mathrm{M}=$ $\mathrm{Li}+, \mathrm{Na}+\mathrm{K}+, \mathrm{Rb}+$ and $\mathrm{Cs}+$ ), theoretical views. Appl. Organomet. Chem. 2003, 17, 635-640, https://doi.org/10.1002/aoc.469.

55. Ilkhani, A.R.; Monajjemi, M. The pseudo Jahn-Teller effect of puckering in pentatomic unsaturated rings C4AE5, A=N, P, As, E=H, F, Cl. Computational and Theoretical Chemistry 2015, 1074, 19-25, http://dx.doi.org/10.1016\%2Fj.comptc.2015.10.006.

56. Monajjemi, M. Non-covalent attraction of $\mathrm{B} 2 \mathrm{~N}(-, 0)$ and repulsion of $\mathrm{B} 2 \mathrm{~N}(+)$ in the BnNnring: a quantum rotatory due to an external field. Theor. Chem. Acc. 2015, 134, 77, https://doi.org/10.1007/s00214-0151668-9.

57. Monajjemi, M.; Naderi, F.; Mollaamin, F.; Khaleghian, M. Drug design outlook by calculation of second virial coefficient as a nano study. Journal of the mexican chemical society 2012, 56, 207-211, https://doi.org/10.29356/jmcs.v56i2.323.

58. Monajjemi, M.; Bagheri, S.; Moosavi, M.S.; Moradiyeh, N.; Zakeri, M.; Attarikhasraghi, N.; Saghayimarouf, N.; Niyatzadeh, G.; Shekarkhand, M.; Khalilimofrad, M.S. Symmetry Breaking of B2N (-, 0,+): An Aspect of the Electric Potential and Atomic Charges. Molecules 2015, 20, 21636-21657, https://doi.org/10.3390/molecules201219769.

59. Monajjemi, M.; Mohammadian, N.T. S-NICS: An aromaticity criterion for nano molecules. Journal of Computational and Theoretical Nanoscience 2015, 12, 4895-4914, https://doi.org/10.1166/jctn.2015.4458.

60. Monajjemi, M.; Ketabi, S.; Hashemian Zadeh, M.; Amiri, A. Simulation of DNA bases in water: Comparison of the Monte Carlo algorithm with molecular mechanics force fields. Biochemistry (Moscow) 2006, 71, S1S8, https://doi.org/10.1134/s0006297906130013.

61. Monajjemi, M.; Lee, V.S.; Khaleghian, M.; Honarparvar, B.; Mollaamin, F. Theoretical Description of Electromagnetic Nonbonded Interactions of Radical, Cationic, and Anionic NH2BHNBHNH2 Inside of the B18N18 Nanoring. The Journal of Physical Chemistry C 2010, 114, 15315-15330, https://doi.org/10.1021/jp104274z.

62. Monajjemi, M.; Boggs, J.E. A New Generation of BnNn Rings as a Supplement to Boron Nitride Tubes and Cages. The Journal of Physical Chemistry A 2013, 117, 1670-1684, http://dx.doi.org/10.1021/jp312073q.

63. Monajjemi, M. Non bonded interaction between $\mathrm{BnNn}$ (stator) and $\mathrm{BN}(-, 0,+) \mathrm{B}$ (rotor) systems: A quantum rotation in IR region. Chem. Phys. 2013, 425, 29-45, https://doi.org/10.1016/j.chemphys.2013.07.014.

64. Monajjemi, M.; Wayne, R.; Boggs, J.E. NMR contour maps as a new parameter of carboxyl's OH groups in amino acids recognition: A reason of tRNA-amino acid conjugation. Chem. Phys. 2014, 433, 1-11, https://doi.org/10.1016/j.chemphys.2014.01.017.

65. Monajjemi, M. Quantum investigation of non-bonded interaction between the B15N15 ring and BH2NBH2 (radical, cation, anion) systems: a nano molecularmotor. Struct. Chem. 2012, 23, 551-580, http://dx.doi.org/10.1007/s11224-011-9895-8.

66. Monajjemi, M. Metal-doped graphene layers composed with boron nitride-graphene as an insulator: a nanocapacitor. J. Mol. Model. 2014, 20, 2507, https://doi.org/10.1007/s00894-014-2507-y.

67. Mollaamin, F.; Monajjemi, M.; Mehrzad, J. Molecular Modeling Investigation of an Anti-cancer Agent Joint to SWCNT Using Theoretical Methods. Fullerenes, Nanotubes and Carbon Nanostructures 2014, 22, 738751, https://doi.org/10.1080/1536383X.2012.731582.

68. Monajjemi, M.; Ketabi, S.; Amiri, A. Monte Carlo simulation study of melittin: Protein folding and temperature dependence. Russian Journal of Physical Chemistry 2006, 80, S55-S62, https://doi.org/10.1134/S0036024406130103.

69. Monajjemi, M.; Heshmata, M.; Haeria, H.H. QM/MM model study on properties and structure of some antibiotics in gas phase: Comparison of energy and NMR chemical shift. Biochemistry (Moscow) 2006, 71, S113-S122, https://doi.org/10.1134/S0006297906130190.

70. Monajjemi, M.; Afsharnezhad, S.; Jaafari, M.R.; Abdolahi, T.; Nikosade, A.; Monajemi, H. NMR shielding and a thermodynamic study of the effect of environmental exposure to petrochemical solvent on DPPC, an important component of lung surfactant. Russian Journal of Physical Chemistry A 2007, 81, 1956-1963, https://doi.org/10.1134/S0036024407120096.

71. Mollaamin, F.; Noei, M.; Monajjemi, M.; Rasoolzadeh, R. Nano theoretical studies of fMet-tRNA structure in protein synthesis of prokaryotes and its comparison with the structure of fAla-tRNA. Afr. J. Microbiol. Res. 2011, 5, 2667-2674, https://doi.org/10.5897/AJMR11.310.

72. Monajjemi, M.; Heshmat, M.; Haeri, H.H.; Kaveh, F. Theoretical study of vitamin properties from combined QM-MM methods: Comparison of chemical shifts and energy. Russian Journal of Physical Chemistry 2006, 80, 1061, https://doi.org/10.1134/S0036024406070119. 
73. Monajjemi, M.; Chahkandi, B. Theoretical investigation of hydrogen bonding in Watson-Crick, Hoogestein and their reversed and other models: comparison and analysis for configurations of adenine-thymine base pairs in 9 models. Journal of Molecular Structure: THEOCHEM 2005, 714, 43-60, https://doi.org/10.1016/j.theochem.2004.09.048.

74. Monajjemi, M.; Honarparvar, B.; Haeri, H.H.; Heshmat, M. An ab initio quantum chemical investigation of solvent-induced effect on 14N-NQR parameters of alanine, glycine, valine, and serine using a polarizable continuum model. Russian Journal of Physical Chemistry 2006, 80, S40, https://doi.org/10.1134/S0036024406130073.

75. Monajjemi, M.; Farahani, N.; Mollaamin, F. Thermodynamic study of solvent effects on nanostructures: phosphatidylserine and phosphatidylinositol membranes. Phys. Chem. Liq. 2012, 50, 161-172, https://doi.org/10.1080/00319104.2010.527842.

76. Monajjemi, M.; Ahmadianarog, M. Carbon Nanotube as a Deliver for Sulforaphane in Broccoli Vegetable in Point of Nuclear Magnetic Resonance and Natural Bond Orbital Specifications. Journal of computational and theoretical nanoscience 2014, 11, 1465-1471, https://doi.org/10.1166/jctn.2014.3519.

77. Monajjemi, M.; Ghiasi, R.; Ketabi, S.; Passdar, H.; Mollaamin, F. A theoretical study of metal-stabilised rare tautomers stability: $\mathrm{N} 4$ metalated cytosine $(\mathrm{M}=\mathrm{Be} 2+, \mathrm{Mg} 2+, \mathrm{Ca} 2+, \mathrm{Sr} 2+$ and $\mathrm{Ba} 2+)$ in gas phase and different solvents. Journal of chemical research 2004, 2004, 11-18, https://doi.org/10.3184/030823404323000648.

78. Monajjemi, M.; Baei, M.T.; Mollaamin, F. Quantum mechanic study of hydrogen chemisorptions on nanocluster vanadium surface. Russian Journal of Inorganic Chemistry 2008, 53, 1430-1437, https://doi.org/10.1134/S0036023608090143.

79. Mollaamin, F.; Baei, M.T.; Monajjemi, M.; Zhiani, R.; Honarparvar, B. A DFT study of hydrogen chemisorption on V (100) surfaces. Russian Journal of Physical Chemistry A, Focus on Chemistry 2008, 82, 2354-2361, https://doi.org/10.1134/S0036024408130323.

80. Monajjemi, M.; Honarparvar, B.; Nasseri, S.M.; Khaleghian, M. NQR and NMR study of hydrogen bonding interactions in anhydrous and monohydrated guanine cluster model: A computational study. J. Struct. Chem. 2009, 50, 67-77, https://doi.org/10.1007/s10947-009-0009-z.

81. Monajjemi, M.; Aghaie, H.; Naderi, F. Thermodynamic study of interaction of TSPP, CoTsPc, and FeTsPc with calf thymus DNA. Biochemistry (Moscow) 2007, 72, 652-657, https://doi.org/10.1134/S0006297907060089.

82. Monajjemi, M.; Heshmat, M.; Aghaei, H.; Ahmadi, R.; Zare, K. Solvent effect on 14 N NMR shielding of glycine, serine, leucine, and threonine: comparison between chemical shifts and energy versus dielectric constant. Bull. Chem. Soc. Ethiop. 2007, 21, https://doi.org/10.4314/bcse.v21i1.61387.

83. Monajjemi, M.; Rajaeian, E.; Mollaamin, F.; Naderi, F.; Saki, S. Investigation of NMR shielding tensors in 1,3 dipolar cycloadditions: solvents dielectric effect. Phys. Chem. Liq. 2008, 46, 299-306, https://doi.org/10.1080/00319100601124369.

84. Mollaamin, F.; Varmaghani, Z.; Monajjemi, M. Dielectric effect on thermodynamic properties in vinblastine by DFT/Onsager modelling. Phys. Chem. Liq. 2011, 49, 318-336, https://doi.org/10.1080/00319100903456121.

85. Monajjemi, M.; Honaparvar, B.; Khalili Hadad, B.; Ilkhani, A.; Mollaamin, F. Thermo-Chemical Investigation and NBO Analysis of Some anxileotic as Nano- Drugs. African journal of pharmacy and pharmacology 2010, 4, 521-529.

86. Monajjemi, M.; Khaleghian, M.; Mollaamin, F. Theoretical study of the intermolecular potential energy and second virial coefficient in the mixtures of $\mathrm{CH} 4$ and $\mathrm{Kr}$ gases: a comparison with experimental data. Mol. Simul. 2010, 36, 865-870, https://doi.org/10.1080/08927022.2010.489557.

87. Monajjemi, M.; Khosravi, M.; Honarparvar, B.; Mollaamin, F. Substituent and solvent effects on the structural bioactivity and anticancer characteristic of catechin as a bioactive constituent of green tea. Int. J. Quantum Chem 2011, 111, 2771-2777, https://doi.org/10.1002/qua.22612.

88. Tahan, A.; Monajjemi, M. Solvent Dielectric Effect and Side Chain Mutation on the Structural Stability of Burkholderia cepacia Lipase Active Site: A Quantum Mechanical/Molecular Mechanics Study. Acta Biotheor. 2011, 59, 291-312, https://doi.org/10.1007/s10441-011-9137-x.

89. Monajjemi, M.; Khaleghian, M. EPR Study of Electronic Structure of [CoF6]3-and B18N18 Nano Ring Field Effects on Octahedral Complex. J. Cluster Sci. 2011, 22, 673-692, https://doi.org/10.1007/s10876011-0414-2.

90. Monajjemi, M.; Mollaamin, F. Molecular Modeling Study of Drug-DNA Combined to Single Walled Carbon Nanotube. J. Cluster Sci. 2012, 23, 259-272https://doi.org/10.1007/s10876-011-0426-y.

91. Mollaamin, F.; Monajjemi, M. Fractal dimension on carbon nanotube-polymer composite materials using percolation theory. Journal of Computational and Theoretical Nanoscience 2012, 9, 597-601, https://doi.org/10.1166/jctn.2012.2067.

92. Mahdavian, L.; Monajjemi, M. Alcohol sensors based on SWNT as chemical sensors: Monte Carlo and Langevin dynamics simulation. Microelectron. J. $\quad \mathbf{2 0 1 0}, \quad 41, \quad$ 142-149, https://doi.org/10.1016/j.mejo.2010.01.011. 
93. Monajjemi, M.; Falahati, M.; Mollaamin, F. Computational investigation on alcohol nanosensors in combination with carbon nanotube: a Monte Carlo and ab initio simulation. Ionics 2013, 19, 155-164, https://doi.org/10.1007/s11581-012-0708-X.

94. Jian, S.; Gang, Y.; Ke, S.; Yushun, W.; Chuming, L.; Hideki, A.; Qibin, G.; Ashley, A.; Fang, L.Structural basis for resptor recognition by novel coronavirus from wuhan, Nature Research 2020, https://doi.org/10.21203/rs.2.24749/v1.

95. Li, F. Receptor Recognition Mechanisms of Coronaviruses: a Decade of Structural Studies. J. Virol. 2015, 89, 1954, http://dx.doi.org/10.1128/JVI.02615-14.

96. Bonavia, A.; Zelus, B.D.; Wentworth, D.E.; Talbot, P.J.; Holmes, K.V. Identification of a Receptor-Binding Domain of the Spike Glycoprotein of Human Coronavirus HCoV-229E. J. Virol. 2003, 77, 2530, http://dx.doi.org/10.1128/JVI.77.4.2530-2538.2003.

97. Mou, H.; Raj, V.S.; van Kuppeveld, F.J.M.; Rottier, P.J.M.; Haagmans, B.L.; Bosch, B.J. The Receptor Binding Domain of the New Middle East Respiratory Syndrome Coronavirus Maps to a 231-Residue Region in the Spike Protein That Efficiently Elicits Neutralizing Antibodies. J. Virol. 2013, 87, 9379, http://dx.doi.org/10.1128/JVI.01277-13.

98. Raj, V.S.; Mou, H.; Smits, S.L.; Dekkers, D.H.W.; Müller, M.A.; Dijkman, R.; Muth, D.; Demmers, J.A.A.; Zaki, A.; Fouchier, R.A.M.; Thiel, V.; Drosten, C.; Rottier, P.J.M.; Osterhaus, A.D.M.E.; Bosch, B.J.; Haagmans, B.L. Dipeptidyl peptidase 4 is a functional receptor for the emerging human coronavirus-EMC. Nature 2013, 495, 251-254, http://dx.doi.org/10.1038/nature12005.

99. Yang, Y.; Du, L.; Liu, C.; Wang, L.; Ma, C.; Tang, J.; Baric, R.S.; Jiang, S.; Li, F. Receptor usage and cell entry of bat coronavirus HKU4 provide insight into bat-to-human transmission of MERS coronavirus. Proceedings of the National Academy of Sciences 2014, 111, 12516, http://dx.doi.org/10.1073/pnas.1405889111.

100. Promkuntod, N.; van Eijndhoven, R.E.W.; de Vrieze, G.; Gröne, A.; Verheije, M.H. Mapping of the receptor-binding domain and amino acids critical for attachment in the spike protein of avian coronavirus infectious bronchitis virus. Virology 2014, 448, 26-32, http://dx.doi.org/10.1016/j.virol.2013.09.018.

101. Peng, G.; Sun, D.; Rajashankar, K.R.; Qian, Z.; Holmes, K.V.; Li, F. Crystal structure of mouse coronavirus receptor-binding domain complexed with its murine receptor. Proceedings of the National Academy of Sciences 2011, 108, 10696.

102. Peng, G.; Xu, L.; Lin, Y.-L.; Chen, L.; Pasquarella, J.R.; Holmes, K.V.; Li, F. Crystal structure of bovine coronavirus spike protein lectin domain. J. Biol. Chem. 2012, 287, 41931-41938, http://dx.doi.org/10.1074/jbc.M112.418210.

103. Langereis, M.A.; van Vliet, A.L.W.; Boot, W.; de Groot, R.J. Attachment of Mouse Hepatitis Virus to OAcetylated Sialic Acid Is Mediated by Hemagglutinin-Esterase and Not by the Spike Protein. J. Virol. 2010, 84, 8970, http://dx.doi.org/10.1128/JVI.00566-10.

104. Lana, R.M.; Coelho, F.C.; Gomes, M.F.d.C.; Cruz, O.G.; Bastos, L.S.; Villela, D.A.M.; Codeço, C.T. Emergência do novo coronavírus (SARS-CoV-2) e o papel de uma vigilância nacional em saúde oportuna e efetiva. Cad. Saude Publica 2020, 36, http://doi.org/10.1590/0102-311X00019620.

105. Baglivo, M.; Baronio, M.; Natalini, G.; Beccari, T.; Chiurazzi, P.; Fulcheri, E.; Petralia, P.P.; Michelini, S.; Fiorentini, G.; Miggiano, G.A.; Morresi, A.; Tonini, G.; Bertelli, M. Natural small molecules as inhibitors of coronavirus lipid-dependent attachment to host cells: a possible strategy for reducing SARS-COV-2 infectivity? SARS-COV-2 lipid-dependent attachment to host cells. Acta Bio Medica Atenei Parmensis 2020, 91, 161-164, https://doi.org/10.23750/abm.v91i1.9402.

106. Thomson, G. COVID-19: Social distancing, ACE 2 receptors, protease inhibitors and beyond? Int. J. Clin. Pract. 2020, 74, e13503, https://doi.org/10.1111/ijcp.13503.

107. Giuseppe, L.; Mario, P. The critical role of laboratory medicine during coronavirus disease 2019 (COVID19) and other viral outbreaks. Clinical Chemistry and Laboratory Medicine (CCLM) 2020, 58, 1063-1069, https://doi.org/10.1515/cclm-2020-0240.

108. Karako, K.; Song, P.; Chen, Y.; Tang, W. Analysis of COVID-19 infection spread in Japan based on stochastic transition model. Biosci. Trends 2020, 14, 134-138, https://doi.org/10.5582/bst.2020.01482.

109. Wu, A.; Peng, Y.; Huang, B.; Ding, X.; Wang, X.; Niu, P.; Meng, J.; Zhu, Z.; Zhang, Z.; Wang, J. Genome composition and divergence of the novel coronavirus (2019-nCoV) originating in China. Cell Host Microbe 2020, https://doi.org/10.1016/j.chom.2020.02.001.

110. Cheepsattayakorn, A.; Cheepsattayakorn, R. Proximal origin and phylogenetic analysis of COVID-19 (2019-nCoV or SARS-CoV-2). EC Microbiology 2020, 19, 9-12.

111. Guo, Y.-R.; Cao, Q.-D.; Hong, Z.-S.; Tan, Y.-Y.; Chen, S.-D.; Jin, H.-J.; Tan, K.-S.; Wang, D.-Y.; Yan, Y. The origin, transmission and clinical therapies on coronavirus disease 2019 (COVID-19) outbreak - an update on the status. Military Medical Research 2020, 7, 11, https://doi.org/10.1186/s40779-020-00240-0.

112. Rothan, H.A.; Byrareddy, S.N. The epidemiology and pathogenesis of coronavirus disease (COVID-19) outbreak. J. Autoimmun. 2020, 109, 102433, https://doi.org/10.1016/j.jaut.2020.102433.

113. Koenig, K.L.; Bey, C.K.; McDonald, E.C. 2019-nCoV: The Identify-Isolate-Inform (3I) Tool Applied to a Novel Emerging Coronavirus. West. J. Emerg. Med. 2020, 21, 184, https://dx.doi.org/10.5811/westjem.2020.1.46760. 
114. Dany, L. COVID-19: protecting health-care workers. The Lancet 2020, 395, 922 , https://doi.org/10.1016/S0140-6736(20)30644-9.

115. McCloskey, B.; Zumla, A.; Ippolito, G.; Blumberg, L.; Arbon, P.; Cicero, A.; Endericks, T.; Lim, P.L.; Borodina, M. Mass gathering events and reducing further global spread of COVID-19: a political and public health dilemma. The Lancet 2020, 395, 1096-1099, https://doi.org/10.1016/S0140-6736(20)30681-4.

116. Jin, Z.; Du, X.; Xu, Y.; Deng, Y.; Liu, M.; Zhao, Y.; Zhang, B.; Li, X.; Zhang, L.; Peng, C.; Duan, Y.; Yu, J.; Wang, L.; Yang, K.; Liu, F.; Jiang, R.; Yang, X.; You, T.; Liu, X.; Yang, X.; Bai, F.; Liu, H.; Liu, X.; Guddat, L.W.; Xu, W.; Xiao, G.; Qin, C.; Shi, Z.; Jiang, H.; Rao, Z.; Yang, H. Structure-based drug design, virtual screening and high-throughput screening rapidly identify anti-viral leads targeting COVID-19. BioRxiv 2020, https://doi.org/10.1038/s41586-020-2223-y.

117. Wu, Y.; Guo, C.; Tang, L.; Hong, Z.; Zhou, J.; Dong, X.; Yin, H.; Xiao, Q.; Tang, Y.; Qu, X.; Kuang, L.; Fang, X.; Mishra, N.; Lu, J.; Shan, H.; Jiang, G.; Huang, X. Prolonged presence of SARS-CoV-2 viral RNA in faecal samples. The Lancet Gastroenterology \& Hepatology 2020, 5, 434-435, https://doi.org/10.1016/S2468-1253(20)30083-2.

118. Mitjà, O.; Clotet, B. Use of anti-viral drugs to reduce COVID-19 transmission. The Lancet Global Health 2020, 8, e639-e640, https://doi.org/10.1016/S2214-109X(20)30114-5.

119. Bashyam, A.M.; Feldman, S.R. Should patients stop their biologic treatment during the COVID-19 pandemic. Journal of Dermatological Treatment 2020, 31, 317-318, https://doi.org/ 10.1080/ 09546634. 2020.1742438 . 